\title{
G2C Acceptance in Malaysia: Trust, Perceived Risk and Political Efficacy
}

\author{
Ramlah Hussein, Norshidah Mohamed, Abdul Rahman Ahlan, Murni Mahmud and Umar Aditiawarman \\ Department of Information Systems, Faculty of ICT, International Islamic University Malaysia \\ ramlah@iiu.edu.my, norshidah@iiu.edu.my; arahman@iiu.edu.my; murni@iiu.edu.my; oemar99@gmail.com
}

\begin{abstract}
Electronic government or e-government has long been known as a breakthrough of a new form of communication and transaction between the government and citizens, the government and industries, and among the government agencies. Simply, e-government is meant not only to help the government to accomplish its daily administrative activities but also to provide an easier way to communicate with external entities such as citizens and businesses throughout the utilization of information and communication technology (ICT). With the implementation of e-government in Malaysia, study about Government to Citizens (G2C) adoption could be significantly important in reflecting its progress. Against this backdrop, this research intends to study G2C adoption in Malaysia by adopting Technology Acceptance Model (TAM) theory as a framework. We investigated factors that are believed to influence citizens' intention to use G2C system. The factors were trust, perceived risk and political efficacy.
\end{abstract}

Keywords: TAM, Intention to use, Perceived Risk, Trust, Political Efficacy

\section{INTRODUCTION}

In the middle of information age and with the proliferation of innovative ICT from time to time, the government of Malaysia has been cautiously taking the opportunity to reform their tasks through the utilization of ICT in delivering its services and information to the citizens more effective and efficient. The use of ICT not only helps the government to accomplish its daily administrative activities but also provide an easier way to communicate and transact with the citizens or industries.

In 1996, the government initiated Multimedia Super Corridor Malaysia (MSC-Malaysia) as a platform to build a competitive market for the ICT companies and industries. MSC Malaysia has hosted more than 900 multinational and local companies that focused on ICT and multimedia products, services, solutions, and research and development. As one of the MSC Malaysia Flagship Applications, e-government initiative was introduced to improve the way in which the government delivers the services to its citizens and industries. The projects under the e-government flagship that have been started since ten years ago were aimed at building a more effective and efficient way to communicate and transact with the citizens and industries. One of the e-government projects that have a great impact to the society is Online Tax System or e-Filing.

In 2006, the Inland Revenue Board Malaysia (IRBM) on behalf of the government introduced the e-Filing system. The objectives of e-Filing are to facilitate tax compliance and to provide taxpayers service through the use of Internet technologies and WWW. By using e-Filing system, taxpayers are able to prepare report and pay their tax online. Administratively, e-Filing may offer a potential benefit to the government because the process of tax returns by the citizens can be managed effectively via the enabling technologies. It is reported that the number of e-Filing users has outnumbered the expectation of 500,000 users become 874,814 users in 2007; an increase of 369.5 percent since it was first introduced [11]. But the obstacles remain put concern on taxpayers who are really anxious about the technology, lacking of technical skills, or do not trust of any online transaction.

One of the most important reasons of e-government implementation is to embrace citizens and businesses closer to their governments. Consequently, the interactions and transactions can be established at anywhere and anytime. Analogous to e-commerce technology, which allows businesses to transact with each other more efficiently and effectively (B2B) and brings customers closer to businesses (B2C), e-government aims to make the interaction between government and citizens (G2C), government and business enterprises 
(G2B), government and its own employee (G2E), and inter-agency relationships (G2G) more friendly, convenient, transparent, and inexpensive.

According to Gronlund and Horan [16], e-government can be defined as "the use by government agencies of information technologies that have the ability to transform relations with citizens, businesses, and other arms of governments. These technologies can serve a variety of different ends: better delivery of government services to citizens, improved interactions with business and industry, citizen empowerment through access to information, or more efficient government management. The resulting benefits can be less corruption, increased transparency, greater convenience, revenue growth, and/or cost reductions." (pp. 718-719). Chen et al. [6] identified the advantages that can be offered by e-government such as removed boundaries (more approachable government), enhanced accessibility (access to information and services), improved service quality (convenient, inexpensive, reliable services), integrated agencies (cross-agency initiative), improved reputation (modern nation, investment), and greater citizen participation.

E-government is not always come up with the success story as it promised. Several studies have shown empirical evidence that e-government is running smoothly in developed countries rather than developing countries. Chen et al. [6] conducted a comparative study of e-government implementation between developed countries and developing countries. They found some main differences affecting the implementation based on these categories; historical and cultural issues of the country, technical staff, infrastructure, citizen' characteristics, government officers.

This has led the researchers to investigate the factors that might contribute to taxpayer's intention to use eFiling system. Generally, the study adopts TAM as basic research model to explain the status of egovernment adoption by citizen and expands the model to identify determinants of TAM in the context of egovernment adoption in Indonesia.

\section{REVIEW OF THE LITERATURE}

With the implementation of e-government in Malaysia, a study about Government to Citizens (G2C) adoption could be significantly important in reflecting its progress. Apparently, most of the established studies on egovernment adoption are rooted from the theoretical model of e-commerce adoption. Some of the theories that constitute user's intention to use technology such as, Technology Acceptance Model (TAM), Diffusion of Innovation (DOI), Perceived Characteristics of Innovating (PCl), Trust and Perceived Risk, were empirically tested in e-commerce adoption research [26, 15, 21].

Since both e-commerce and e-government have the same characteristics, there is no doubt that such studies of technology adoption in e-commerce could also be applicable in e-government context. Therefore, this study aims to integrate the constructs from established e-commerce adoption models that are mainly based on TAM, and web trust. In addition, some constructs such as, perceived risk, and political self efficacy are believed to be the determinants of e-government adoption.

\subsection{Technology Acceptance Model (TAM)}

Studying the acceptance and use of ICT has been the focus of many researchers in IS research for the last two decades. Adopted from the Theory of Reasoned Action (TRA) originated by Fishbein and Ajzen [12], Davis [8] in his study developed Technology Acceptance Model (TAM), which is specifically meant to explain computer usage behaviour. TAM is one of the most common theories applied in IS research and has established itself as a parsimonious powerful model in explaining and predicting technology acceptance [10]. The purpose of TAM is to provide an explanation of the determinants of computer acceptance in general as well as a basis for tracing the impact of external variables on internal beliefs, attitudes and intentions [9].

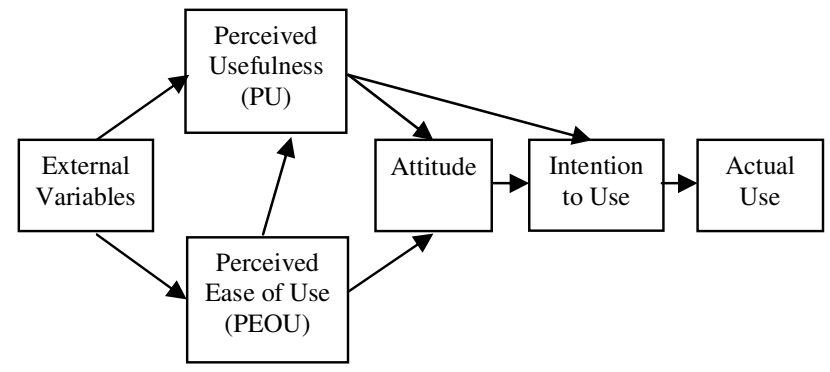

Figure 1: Technology Acceptance Model (TAM) by Davis [8] 
TAM posits that perceived usefulness and perceived ease of use influence computer user's intention and actual usage behaviour. According to Davis [9], perceived usefulness is defined as "the degree to which a person believes that using a particular system would enhance his or her job performance". Meanwhile the perceived ease of use refers to "the degree to which a person believes that using a particular system would free of effort". The proliferation use of TAM theory as a research model in predicting usage behaviour of new technologies in recent years has also led researchers and practitioners apply this theory in the Internet and WWW context $[13,20,6]$. However, only few researchers extended the TAM theory by associating with other variables or theories to study e-government adoption. In most of their studies Carter \& Belanger $[4,5]$ and Phang et al. [27] combined Diffusion of Innovation (DOI) theory with TAM to provide a comprehensive model of e-government adoption. Other studies conducted by Al-Adawi et al. [1] and Warkentin et al. [31] also combined TAM with Trust and Perceived Risk.

\subsection{Trust and Perceived Risk}

The dimensions of trust and perceived risk could be the factors that contribute to citizen's intention to use of e-government system. It cannot be denied that trust become a central issue in all daily interactions, communications, transactions and practices, especially when it's done remotely, through the internet. Although there is little agreement in the literature about how to define citizen trust in government or how it is gained and lost, most researchers agree that it is an important determinant of public action and cooperation (Thomas, 1998; [32, 26].

In his research, Rotter's [29] defined trust as "an expectancy that the promise of an individual or group can be relied upon". This definition has led to some of the definitions of citizen's trust in e-government context. Zucker [34] divided trust into three modes, these include; characteristics-based trust, process-based trust, and institution-based trust. Characteristics-based trust is associated with personal characteristics such as, gender, age, race, nationality, etc. Researchers [32, 31] agreed that this mode of trust may not feasible and difficult to apply in e-government environment. Since characteristics-based trust is related to social issues, it may explicitly contradict the legal statutes if it is applied in the study.

Process-based trust is a trust based on individual's prior experience when dealing with government. This mode of trust can be created in e-government context if the government could ensure the e-government technologies are well prepared and maintained with high security system before it is implemented. Furthermore, encouraging and convincing the citizens that they would have same experience when they use e-government compared to traditional system are also one of the factors in building up citizen's trust. Lastly, institution-based trust is associated with individual perceptions of the institutional environment such as; the structure, regulation and legislation that make an environment feel safe and trustworthy.

Belanger and Carter [3] suggested two types of trusts in e-government context. Firstly, trust of the Internet, is identified as a key predictor of e-service adoption [4, 21, 26]. This type of trust is associated with the institution-based trust because of the communities that exist on the internet are varied according to their norms, expectations, and values [26]. Secondly, trust of the government, is related to citizen confidence in the ability of an agency to provide online services.

The information and services provided by the government through the internet are not automatically building up people trust on how they are delivered. Privacy, security, and fraud on the internet are still surrounding people's concern in adopting e-government technologies. Nelson (1997) also added that user's trust in webbased technologies is affected by such issues in networks security, confidentiality, reliability of information, and jurisdiction. Thus citizen must have confident in both the government and the technologies [5].

Trust is essentially needed only in uncertain situations since trust effectively means assume risks and become vulnerable to trusted parties [17]. According to Pavlou [26], trust is found to be a significant antecedent of perceived risk. If there was no risk and actions could be taken with complete certainty no trust would be required [1]. Prior researches have discussed the relationship between trust and perceived risk $[26,3,1,19]$. It was found that perceived risk decreases when trust occurs. However, since risk itself is difficult to measure objectively, established research has predominately defined perceived risk as "the citizen's subjective expectation of suffering a loss in pursuit of a desired outcome" [31, 3]. Researchers [26, $31,3]$ agreed that trust is viewed as a determinant of intention to use directly or indirectly via perceived risk.

\subsection{Political Self-Efficacy}


Political self-efficacy is believed to be a significant factor that contributes to citizen's trust in dealing with government. Prior studies have been conducted to measure the determinants of trust in e-government context. However, only few studies have been found to measure citizen trust in using e-government from political self-efficacy aspect. As citizen political self-efficacy has been exist long before the e-government was developed, it is necessary to involve this construct in the study. According to Compeau and Higgins [7], based on original definition of self-efficacy first coined by Bandura [2], self-efficacy was defined as"...the belief that one has the capability to perform a particular behavior". This leads to the definition of political self efficacy as defined by Parent et al. [25] as, "the citizen's sense that they have an impact on political developments and their perception of government responsiveness".

Parent et al. [25] divided political self-efficacy into two types. Firstly, internal political self-efficacy is where the citizen feels that they have a contribution and an impact to the political development. Secondly, external self-political efficacy refers to the citizen's perception of overall responsiveness of the government in fulfilling their needs. The findings showed that political self efficacy significantly influenced and explained the citizen's overall trust in government, in turn; the government would be responsive to the citizen needs. It was suggested that government not only to focus on how to improve e-government performance, but also to stress on how to encourage citizens with high pre-existing level of trust to use e-government system.

\section{RESEARCH MODEL}

A number of well established research models have contributed to the development of the conceptual framework of technology adoption and the determinants. Among them are Theory of Reasoned Action (TRA), Theory of Planned Behavior (TPB), Diffusion of Innovation (DOI), Technology Adoption Model (TAM), Unified Theory of Acceptance and Use of technology (UTAUT) and Perceived of Innovating (PCI). Based on previous research, TAM is seen as the most parsimonious model to explain user's intention to use a new technology. The TAM model has been tested in various setting including, email, e-learning, e-banking, ecommerce and e-government.

Following previous studies about e-government adoption, current study adopts TAM as a main research model. Furthermore, factors that are believed to be the predictors of e-government adoption are also included in the proposed research model.

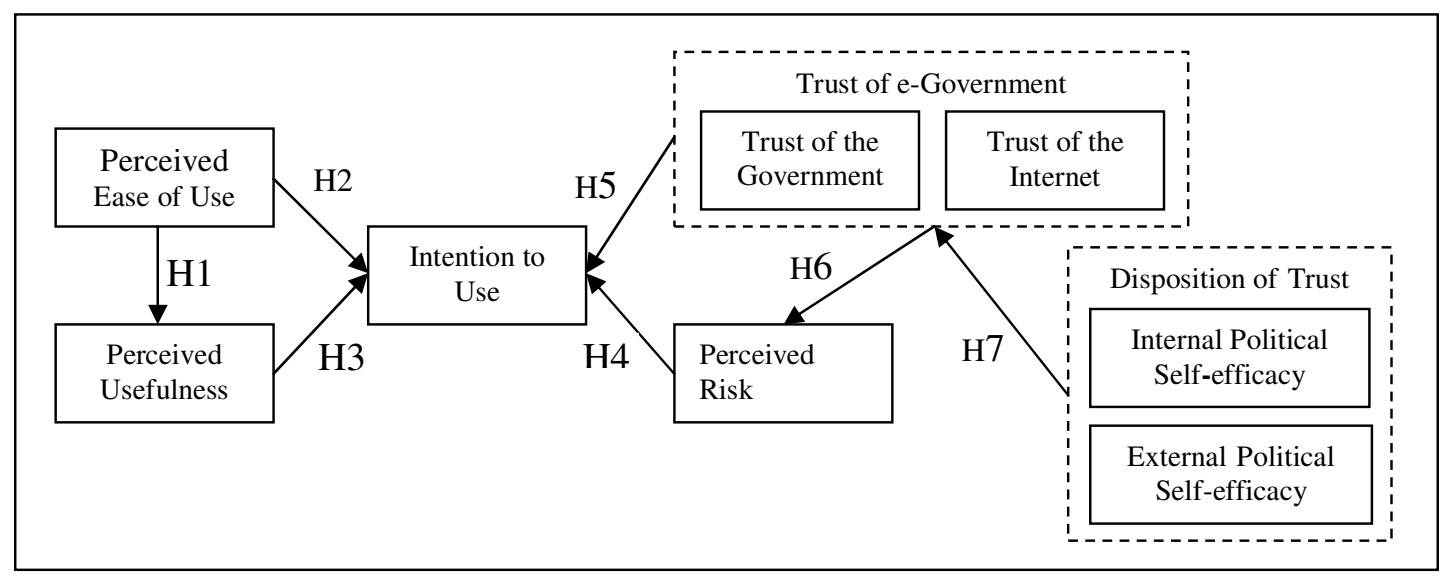

Figure 2: Proposed research model

\section{METHODOLOGY}

This study is shaped with quantitative approach. At the initial stage, the study tends to explore the phenomenon of e-government implementation and its adoption by citizen. In order to obtain a clearer picture about the current implementation of e-government and how it is being used by the citizen, two methods were employed in this preliminary study. The first method is by critically reviewing the past literatures which mainly related to e-government adoption in Malaysia. Thus, the research problem can be defined and the objectives and research framework can be conceptualized based on previous works.

Secondly, to ascertain the proposed model with the current phenomenon, an interview with practitioners, government agencies and citizens was held. The objective of conducting preliminary study is to gain a better 
understanding in e-government adoption by citizens as well as to identify the factors that might contribute to e-government adoption. To evaluate G2C adoption, online tax service is selected for this study. As this system is one of the services provided by the central government and mostly used by the citizens. The next phase is to design the instruments that reflect all the factors involved in the study. The measurements about G2C adoption from previous studies were adapted. A seven point-Likert scale is applied for each item of the question except for the citizen's demographic section. The Likert-scale ranges from $1=$ strongly disagree to $7=$ strongly agree.

\section{RESULTS}

Out of 500 responses collected, there are 411 usable responses that can be used for further data analysis. The rest were unusable due to their incompleteness or other inconsistencies such as typical answer for strongly disagree or strongly agree in all questions. The feedback from respondents yielded a quite high response rate of more than $80 \%$.

Table 1 shows the background and profile of the respondents. Both male and female respondents made up of $47 \%$ and $53 \%$ respectively. About $29.4 \%$ of the respondents held Master degree followed by Doctorate $(25.5 \%)$, Bachelor $(21.7 \%)$ and Diploma (16.3\%). Besides capturing the general profile of the respondents, information about respondent's computer and internet experience are also reported. In term of computer skill, majority of the respondents (61.1\%) were intermediate users followed by $31.9 \%$ and $7.1 \%$ were expert and novice users respectively. Due to the activities on web environment where e-filling take place, it is appropriate to ask the respondents about their general internet experience and usage. Majority of the respondents (44\%) have been using the internet for 6 to 10 years and more than half $(53.7 \%)$ of the respondents were using the internet for 1 to 5 hours a day.

Table 1: Demographic data

\begin{tabular}{|c|c|c|c|}
\hline & & Number & $\%$ \\
\hline \multirow{2}{*}{ Gender } & Male & 193 & 47 \\
\hline & Female & 218 & 53 \\
\hline \multirow{5}{*}{ Age } & Below 25 & 59 & 14.4 \\
\hline & $25-35$ & 135 & 32.8 \\
\hline & $36-45$ & 126 & 30.7 \\
\hline & $46-55$ & 79 & 19.2 \\
\hline & Over 56 & 12 & 2.9 \\
\hline \multirow{4}{*}{ Race } & Malay & 330 & 80.3 \\
\hline & Indian & 31 & 7.5 \\
\hline & Chinese & 30 & 7.3 \\
\hline & Others & 20 & 4.9 \\
\hline \multirow{5}{*}{ Education level } & Diploma & 67 & 16.3 \\
\hline & Bachelor & 89 & 21.7 \\
\hline & Master & 121 & 29.4 \\
\hline & Doctorate & 105 & 25.5 \\
\hline & Others & 29 & 7.1 \\
\hline \multirow{3}{*}{ Computer Skill } & Novice & 29 & 7.1 \\
\hline & Intermediate & 251 & 61.1 \\
\hline & Expert & 131 & 31.9 \\
\hline \multirow{3}{*}{$\begin{array}{l}\text { Computer Use } \\
\text { Experience (years) }\end{array}$} & $1-10$ & 138 & 33.6 \\
\hline & $11-20$ & 233 & 56.7 \\
\hline & $21-30$ & 40 & 9.7 \\
\hline \multirow{5}{*}{$\begin{array}{l}\text { Internet Use } \\
\text { Experience } \\
\text { (years) }\end{array}$} & $1-5$ & 85 & 20.7 \\
\hline & $6-10$ & 181 & 44 \\
\hline & $11-15$ & 110 & 26.8 \\
\hline & $16-20$ & 27 & 6.6 \\
\hline & $21-25$ & 8 & 1.9 \\
\hline \multirow{6}{*}{$\begin{array}{l}\text { Internet Use per } \\
\text { Day } \\
\text { (hours) }\end{array}$} & Below 1 & 3 & 0.7 \\
\hline & $1-5$ & 221 & 53.7 \\
\hline & $6-10$ & 142 & 34.5 \\
\hline & $11-15$ & 31 & 7.5 \\
\hline & $16-20$ & 10 & 2.4 \\
\hline & Over 20 & 4 & 1 \\
\hline
\end{tabular}


The reliability test was conducted based on the collected data from the respondents. According to Nunnaly (1978), a Cronbach score .70 or higher is considered reliable. Each item was assessed by examining the loadings of the items on their respective constructs. Cronbach Alpha was used to assess the reliability of the construct. As depicted in Table 2, all the factors scored relatively high at range between 0.837 and 0.965 , which Perceived Usefulness (PU) scored highest. The reliability test indicates that all the constructs are reliable and suitable to measure the concepts employed in the study.

Table 2: Reliability test

\begin{tabular}{|c|l|c|c|}
\hline No. & Construct & Cronbach $\alpha$ & N of Items \\
\hline 1. & Trust of the Internet & 0.896 & 3 \\
\hline 2. & Trust of the Government & 0.939 & 4 \\
\hline 3. & Perceived Risk & 0.931 & 5 \\
\hline 4. & Internal Political Self-efficacy & 0.915 & 4 \\
\hline 5. & External Political Self-efficacy & 0.837 & 4 \\
\hline 6. & Perceived Ease of Use & 0.948 & 4 \\
\hline 7. & Perceived Usefulness & 0.965 & 4 \\
\hline 8. & Intention to Use & 0.905 & \\
\hline
\end{tabular}

Factor analysis was then conducted to examine convergent and discriminant validity. A principal component method analysis was performed with varimax rotation to test the correlation among the factors. Convergent validity is considered to be satisfactory when items load high on their respective construct or factor. Most of the items exhibited a loading higher than 0.50 on their respective factors. Discriminant validity was evaluated by examining whether each item loaded higher on the construct it measured than on any other construct. Table 3 summarizes the results suggesting that the measurement exhibited somewhat reasonable discriminant validity for the context of this study.

To test the hypotheses of the proposed model, correlation analysis was conducted. Correlation analysis was used to determine both the strength and the direction of the association between the predictor factors; perceived ease of use, perceived usefulness, perceived risk, trust, and political self-efficacy, and criterion factor: intention to use. The results (see Table 4.) indicated that all the predictor variables except perceived risk were positively and significantly related to intention to use. It is also discovered that internal and external political self-efficacy have positive relationship with trust. Thus all the hypotheses were supported except $\mathrm{H} 4$.

Further analysis using multiple regression technique was conducted to analyze the strength of the relationships between the predictor factors and intention to use. A stepwise method was used to examine the contribution of each independent variable to the regression model. The predictor factors were entered sequentially to the analysis based on the highest correlation to the criterion variable. Perceived risk was omitted from the analysis since there was no correlation with intention to use. As shown in Table 5, all predictors except perceived risk accounted about $62.7 \%$ of the variance of Intention to use with $F=113.160$ significant at alpha $<.001$.

Consistent with the previous study about TAM, perceived ease of use was found to influence perceived usefulness and intention to use [3, 4, 6, 20]. Meanwhile the study also confirmed the relationship between user's trust and intention to use e-filing. Surprisingly, perceived risk was found not to correlate with intention to use as hypothesized earlier. The results contradict with several previous study [3,26]. This implicate that doing transaction on e-filing by providing information to the system might not bother the users. The users seemed found that the system is secured and convenience. 
Table 3: Factor analysis

\begin{tabular}{|c|c|c|c|c|c|c|c|c|}
\hline & \multicolumn{8}{|c|}{ Component } \\
\hline & 1 & 2 & 3 & 4 & 5 & 6 & 7 & 8 \\
\hline PUSE3 & .850 & .099 & .130 & .279 & .064 & .225 & .221 & -.010 \\
\hline PUSE2 & .849 & .070 & .150 & .266 & .076 & .195 & .219 & -.025 \\
\hline PUSE4 & .831 & .121 & .119 & .279 & .062 & .206 & .192 & -.001 \\
\hline PUSE1 & .817 & .116 & .159 & .297 & .086 & .215 & .214 & -.013 \\
\hline IPOS4 & .054 & .906 & .111 & .167 & -.014 & .024 & .052 & .017 \\
\hline IPOS2 & .090 & .892 & .060 & .042 & -.016 & .065 & .051 & .016 \\
\hline IPOS5 & .052 & .868 & .122 & .141 & .040 & .062 & .075 & .028 \\
\hline IPOS1 & .035 & .806 & .086 & -.043 & .033 & .053 & .155 & .183 \\
\hline IPOS3 & .132 & .734 & .134 & .148 & -.034 & .052 & .098 & .071 \\
\hline TRSG4 & .063 & .130 & .902 & .056 & .049 & .080 & .147 & .121 \\
\hline TRSG3 & .132 & .125 & .887 & .116 & .083 & .113 & .169 & .093 \\
\hline TRSG1 & .110 & .107 & .879 & .082 & .044 & .101 & .139 & .063 \\
\hline TRSG2 & .175 & .162 & .837 & .161 & .081 & .100 & .096 & -.096 \\
\hline PEOU2 & .333 & .139 & .142 & .815 & .067 & .181 & .208 & .067 \\
\hline PEOU1 & .275 & .145 & .096 & .783 & .114 & .201 & .250 & .000 \\
\hline PEOU3 & .360 & .177 & .134 & .756 & .080 & .225 & .215 & .050 \\
\hline PEOU4 & .409 & .137 & .172 & .721 & .084 & .263 & .227 & -.003 \\
\hline EPOS2 & .106 & -.065 & .146 & .004 & .825 & .003 & .140 & .186 \\
\hline EPOS4 & .062 & .045 & -.059 & .098 & .822 & .017 & .000 & -.036 \\
\hline EPOS1 & .123 & -.054 & .149 & -.020 & .795 & -.011 & .202 & .186 \\
\hline EPOS3 & -.049 & .051 & .028 & .123 & .789 & .086 & -.037 & -.070 \\
\hline TRSI1 & .220 & .072 & .096 & .207 & .034 & .835 & .178 & -.038 \\
\hline TRSI3 & .209 & .071 & .150 & .169 & .080 & .833 & .130 & .009 \\
\hline TRSI2 & .248 & .086 & .125 & .216 & -.010 & .828 & .123 & -.046 \\
\hline IUSE3 & .273 & .170 & .225 & .205 & .097 & .238 & .738 & -.033 \\
\hline IUSE1 & .245 & .155 & .239 & .249 & .149 & .104 & .722 & .053 \\
\hline IUSE2 & .354 & .181 & .205 & .360 & .122 & .165 & .642 & -.124 \\
\hline IUSE4 & .350 & .177 & .211 & .351 & .062 & .235 & .633 & -.070 \\
\hline PRSK1 & -.006 & .135 & .065 & .023 & .080 & -.024 & -.042 & .940 \\
\hline PRSK2 & -.035 & .127 & .077 & .033 & .102 & -.034 & -.021 & .933 \\
\hline
\end{tabular}


Table 4: Correlation analysis

\begin{tabular}{|l|l|l|l|l|l|l|l|l|}
\hline & \multicolumn{1}{|c|}{ PRSK } & \multicolumn{1}{|c|}{ TRSI } & \multicolumn{1}{c|}{ TRSG } & \multicolumn{1}{c|}{ IPOS } & EPOS & PEOU & PUSE & IUSE \\
\hline PRSK & 1 & & & & & & \\
\hline TRSI & -0.37 & 1 & & & & & & \\
\hline TRSG & $.142^{* *}$ & $.319^{* *}$ & 1 & & & & \\
\hline IPOS & $.202^{* *}$ & $.210^{* *}$ & $.296^{* *}$ & 1 & & & \\
\hline EPOS & $.169^{* *}$ & $.118^{*}$ & $.179^{* *}$ & .036 & 1 & & & \\
\hline PEOU & .058 & $.560^{* *}$ & $.370^{* *}$ & $.333^{* *}$ & $.213^{* *}$ & 1 & & \\
\hline PUSE & -.001 & $.551^{* *}$ & $.363^{* *}$ & $.257^{* *}$ & $.192^{* *}$ & $.718^{* *}$ & 1 & \\
\hline IUSE & -.002 & $.524^{* *}$ & $.493^{* *}$ & $.362^{* *}$ & $.258^{* *}$ & $.702^{* *}$ & $.687^{* *}$ & 1 \\
\hline
\end{tabular}

${ }^{* \star}$. Correlation is significant at the 0.01 level (2-tailed)

Note: Perceived Risk (PRSK), Trust of the Internet (TRSI), Trust of the Government (TRSG), Internal Political Efficacy (IPOS), External Political Efficacy (EPOS), Perceived Ease of Use (PEOU), Perceived Usefulness (PUSE), Intention to Use (IUSE)

Table 5: Regression analysis using stepwise method

\begin{tabular}{|l|l|l|l|l|l|}
\hline $\begin{array}{l}\text { Dependent } \\
\text { Variable }\end{array}$ & $\begin{array}{l}\text { Adj. } \\
\mathbf{R}^{2}\end{array}$ & Predictors & $\begin{array}{l}\text { Std. } \\
\text { Beta }\end{array}$ & $\begin{array}{c}\mathbf{t} \\
\text { value }\end{array}$ & $\begin{array}{c}\mathbf{p} \\
\text { Value }\end{array}$ \\
\hline IUSE & .627 & PEOU & .314 & 6.685 & .000 \\
& & PUSE & .300 & 6.579 & .000 \\
& & TRSG & .195 & 5.692 & .000 \\
& & IPOS & .100 & 3.043 & .002 \\
& & EPOS & .084 & 2.675 & .008 \\
& & TRSI & .090 & 2.350 & .019 \\
\hline
\end{tabular}

\section{CONCLUSION}

This study should provide a benefit to both researchers and practitioners, in this context government per se. Hence, the findings might give contributions theoretically and practically. The lack of studies in the area of egovernment specifically G2C adoption is one of the reasons why such study is needed to be conducted in order to obtain a clearer picture of what is going on and the current status of e-government implementation in Malaysia. Some of the theoretical models such as TAM and other contributing factors such as Trust, Perceived Risk, Internal and External Political self-efficacy, have been adopted to explain G2C adoption. Thus, the findings of current study is expected not only to strengthen or refute the previous works that adopt the theories mentioned above, but also, in general, to enrich the body of knowledge and theory of egovernment adoption by citizen. Furthermore, the research model could be used as a reference for any further studies to cater different form of e-government technology.

Practically, G2C system has been implemented in the country for years. But the impact has not yet been experienced fully by the citizens so far. Although a number of studies have been conducted by the government, institution, independent researchers as well as practitioners, most of them were focusing on the infrastructure, policies and organizational perspectives. Hence, the findings of this study are expected to provide an empirical evidence of e-government adoption from the citizen's perspective. The findings also can be used considerably by the government to evaluate current system that could come with the improvement in the future. Initially, this study could provide a platform for evaluating the e-government technology in different form and application.

\section{REFERENCES}

[1] Al-adawi, Z., Yousafzai, S., and Pallister, J. (2005). Conceptual Model of Citizen Adoption of eGovernment. The Second International Conference on Innovation in Information Technology. 1-10.

[2] Bandura, A. (1986). Social foundations of thought and action. Englewood, New Jersey: Prentice Hall. 
[3] Belanger, F., and Carter, L. (2008). Trust and Risk in e-Government Adoption. Journal of Strategic Information Systems. 17(2). 1-15.

[4] Carter, L. and Belanger, F. (2004). Citizen Adoption of Electronic Government Initiatives. Paper Presented at Proceedings of the 37th Hawaii International Conference on System Sciences.

[5] Carter, L. and Belanger, F. (2005). The Utilization of e-Government Services: Citizen Trust, Innovation and Acceptance Factors. Information Systems Journal. 15. 5-25.

[6] Chen, L., Gillenson, M.L. and Sherrell, D.L. (2001). Enticing online consumers: an extended technology acceptance perspective. Information \& Management, 39, 705-719.

[7] Compeau, D.R. and Higgins, C.A. (1995). Computer Self-efficacy: Development of a Measure and Initial Test. MIS Quarterly, 13(3), 319-340.

[8] Davis, F.D. (1986). A technology acceptance model for empirically testing new end-user information systems: theory and results. Doctoral dissertation, Sloan School of Management. Massachusetts Institute of Technology.

[9] Davis, F.D. (1989). Perceived usefulness, perceived ease of use, and user acceptance of information technology. MIS Quarterly, 13, 319-340.

[10] Davis, F.D. \& Venkatesh, V. (1996). A critical assessment of potential measurement biases in the technology acceptance model: three experiments. International Journal of Human-Computer Studies, $45,19-45$.

[11] Bernama. (April 2, 2008). E-Filing, The Preferred Choice Now of Malaysian Taxpayers. Retrieved November 2008, from: http://www.bernama.com/bernama/v5/newsindex.php?id=324143.

[12] Fishbein, M. and Ajzen, I. (1975). Belief, Attitude, Intention and Behaviour: An Introduction to Theory and Research. Reading, MA: Addison-Wesley.

[13] Gardner, C. \& Amoroso, D.L. (2004). Development of an instrument to measure the acceptance of internet technology by consumers. Paper presented at Proceedings of the 37th Hawaii International Conference on System Sciences.

[14] Gefen, D. and Straub, D.W. (2002). Managing User Trust in e-Services. e-Service Journal. 2(1).

[15] Gefen, D., Karahanna, E., and Straub, D.W. (2003). Trust and TAM in Online Shopping: an Integrated Model. MIS Quarterly. 27(1). 51-90.

[16] Gronlund, A and Horan, T.A. (2004). Introducing e-Gov: History, Definitions, and Issues. Communications of the Association for Information Systems. 15. 713-729.

[17] Hosmer, L.T. (1995). The Connection Link between Organizational Theory and Philosophical Ethics. Academy of Management Review. 20(3). 213-237.

[18] Igbaria, M. and Chakrabarti, A. (1990), "Computer anxiety and attitudes towards microcomputer use", Behavior Information Technology, Vol. 9 No. 3, pp. 229-41.

[19] Jarvenpaa, S.L. and Tractinsky, N. (1999). Consumer Trust in an Internet Store: A Cross-Cultural Validation. Journal of Computer-Mediated Communication. 5(2).

[20] Klopping, I.M. and McKinney, E. (2004). Extending the technology acceptance model and tasktechnology fit model to consumer e-commerce. Information Technology, Learning, and Performance Journal, 22(1). 
[21] McKnight, D.H., Choudhury, V., and Kacmar, C. (2002). Developing and Validating Trust Measures for e-Commerce: an Integrative Approach. Information Systems Research. 13(3). 334-359.

[22] Mirchandani, D.A., Johnson, J.H., and Joshi, K. (2008). Perspectives of Citizens towards e-Government in Thailand and Indonesia: A Multigroup Analysis. Information Systems Front. 10(4).

[23] Moore, G. \& Benbasat, I. (1991) Development of an Instrument to Measure the Perceptions of Adopting an Information Technology Innovation. Information Systems Research, 2, 173-191.

[24] Niemi, R.G., Craig, S.C., and Mattei, F. (1991). Measuring Internal Political Efficacy in the 1988 National Election Study. The American Political Science Review. 85(4).

[25] Parent, M., Vandebeek, C.R., and Gemino, A.C. (2004). Building Citizen Trust through e-Government. Paper Presented at Proceedings of the 37th Hawaiian International Conference on Systems Sciences.

[26] Pavlou, P.A. (2003). Consumer Acceptance of Electronic Commerce: Integrating Trust and Risk with the Technology Acceptance Model. International Journal of Electronic Commerce. 7(3). 101-134.

[27] Phang, C.W., Sutanto, J., Li, Y., and Kankanhalli, A. (2005). Senior Citizens' Adoption of Egovernment: In Quest of the Antecedents of Perceived Usefulness. Paper Presented at Proceedings of the 38th Annual Hawaii International Conference on System Sciences..

[28] Rogers, E. M. (1995). Diffusion of Innovations, The Free Press, New York.

[29] Rotter, L.B. (1971). Generalized Expectations for Interpersonal Trust. American Psychologist. 26(5). 443-452.

[30] Venkatesh, V. (2000). Determinants of perceived ease of use integrating control, intrinsic motivation, and emotion into the Technology Acceptance Model. Information System Research, 11(4), 342-365.

[31] Warkentin, M. Gefen, D., Pavlou, P., and Rose, G. (2002). Encouraging Citizen Adoption of eGovernment by Building Trust. Electronic Markets. 12(2). 157-162.

[32] Welch, Eric W. and Charles C. Hinnant. (2003). Internet Use, Transparency and Interactivity Effects on Trust in Government. Paper presented at the 36th Annual Hawaii International Conference on System Sciences. Hawaii.

[33] Zeithaml, V.A., Parasuraman, A., and Malhotra, A. (2002). Service Quality Delivery Through Web Sites: A Critical Review of Extant Knowledge. Journal of the Academy of Marketing Science. 30(4). 362-275.

[34] Zucker, LG. (1986). Production of trust: Institutional sources of economic structure, 1840-1920. Research in Organizational Behaviour. 8:53-111. 